\title{
Alepidea amatymbica Eckl. \& Zeyh.: A Review of Its Traditional Uses, Phytochemistry, Pharmacology, and Toxicology
}

\author{
O. A. Wintola and A. J. Afolayan \\ Medicinal Plant and Economic Development Research Centre, Department of Botany, University of Fort Hare, Alice 5700, South Africa \\ Correspondence should be addressed to A. J. Afolayan; aafolayan@ufh.ac.za
}

Received 6 May 2014; Accepted 16 July 2014; Published 17 August 2014

Academic Editor: Gloria Brusotti

Copyright (C) 2014 O. A. Wintola and A. J. Afolayan. This is an open access article distributed under the Creative Commons Attribution License, which permits unrestricted use, distribution, and reproduction in any medium, provided the original work is properly cited.

\begin{abstract}
Alepidea amatymbica is an important medicinal plant in Southern Africa with a long history of traditional use for the management of conditions like colds, coughs, sore throat, influenza, asthma, and abdominal cramps. Despite the much acclaimed traditional uses of the plant, there is a dearth of scientific information on the review of this plant. Hence, this review is aimed at providing information on the botany, phytochemistry, pharmacology, and toxicology of A. amatymbica. This review uses all the synonyms of the plant obtained from the plant list. Google scholar, Science Direct, PubMed, and Scopus were made use of in addition to the University of Fort Hare's online databases. All the phytochemical studies on Alepidea amatymbica obtained from the literature reported the presence of kaurene-type diterpenoids and their derivatives. Pharmacological areas identified on A. amatymbica fresh and dried extract include antibacterial, antifungal, sedative, astringent, antimalarial, anti-inflammatory, antihelminthes, antihypertensive, anti-HIV, and diuretic activities. Literature search on A. amatymbica revealed the use of cell line, brine shrimps, and rats for the determination of the toxicity in the plant. Clinical trials and product development to fully exploit the medicinal value are also required to validate its folklore use in traditional medicine.
\end{abstract}

\section{Introduction}

The genus Alepidea is a member of the Apiaceae family, placed in the subfamily Saniculoideae, also known as the larger tinsel flower (Eng). Species from the genus have been historically important medicinal plants throughout Africa, occurring mainly in Southern Africa $[1,2]$. Alepidea is a genus of 28 species of herbaceous geophytes endemic to grassland areas of Eastern and Southern Africa northwards to Kenya and Ethiopia $[1,3,4]$. Seven out of the 28 species ( $A$. amatymbica Eckl. \& Zeyh., A. natalensis Wood \& Evans, A. pilifera Weimack, A. longifolia E. Mey. Ex Dümmer, A. setifera N.E.Br., A. comosa Dümmer, and A. macowanii Dümmer) are known to be used commonly for medicinal purposes $[5,6]$. Species of the genus Alepidea are most commonly found in the grasslands of the Eastern Cape Province, Kwazulu Natal, Mpumalanga, South Africa, and other Southern Africa countries like Lesotho, Swaziland, and Zimbabwe [7-9].

Alepidea amatymbica Eckl. \& Zeyh. also known as kalmoes (Afr.); Iqwili (Xhosa); ikhathazo (Zulu) is an important source of traditional medicine [10, 11]. The plant generally grows on stream banks, drainage lines, and forest margins of Northern and Southern Drakensberg Mountains of the Eastern Cape Province, Lesotho, Kwazulu Natal, Swaziland, Mpumalanga, and Northern Province extending towards Zimbabwe [12]. The plant is critically endangered in Zimbabwe [13, 14], vulnerable in Lesotho [15], and listed as at lower risk or near threatened but locally extinct in certain heavily collected areas $[14,16]$. A. amatymbica is an herbaceous perennial plant with dark green leaves arising from a single or branched rhizome. It is a robust, erect plant, up to $2 \mathrm{~m}$ tall in grassland; the leaves form a loose rosette with the margins of the leaves prominently toothed, each tooth ending in a bristle. The flowering stalk hollow up to two meters in height, rising above the surrounding grasses, with numerous small flowers arranged in dense, rounded heads [8]. The inflorescence is widely branched, with a number of small, starshaped white flowers about $250 \mathrm{~mm}$ in diameter (Figure 1). A. amatymbica has a number of synonyms, namely, Alepidea amatymbica var. amatymbica, Alepidea amatymbica 


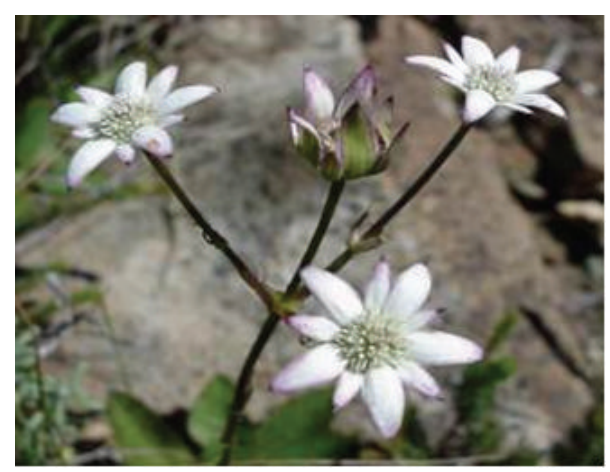

(a)

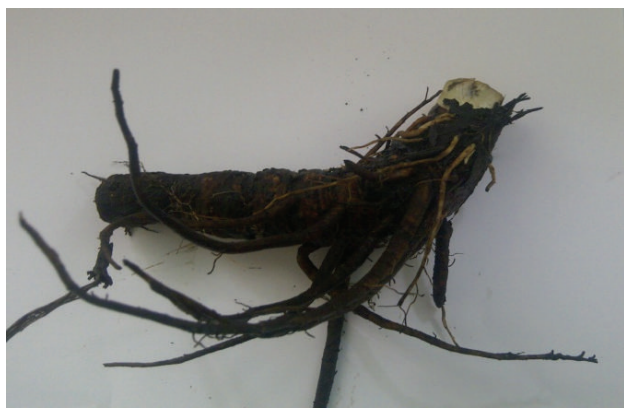

(c)

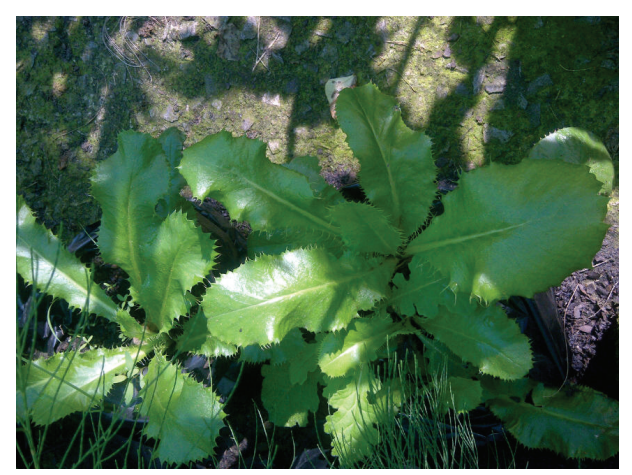

(b)

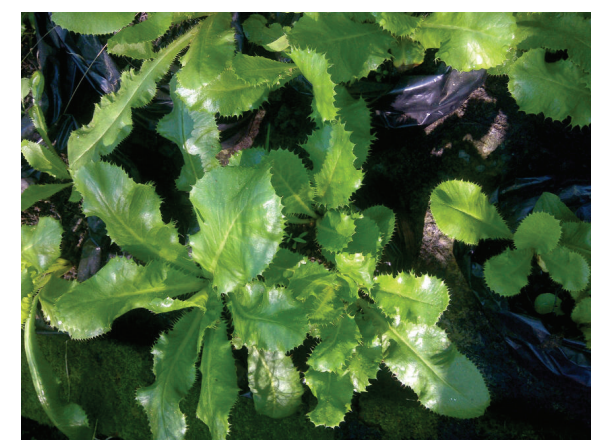

(d)

Figure 1: (a) Alepidea amatymbica Eckl. \& Zeyh. in its natural habitat (source: http://www.Plantzafrica.com), (b) dried rhizome of Alepidea amatymbica, and ((c) and (d)) Alepidea amatymbica growing in the nursery.

var. cordata Eckl. \& Zeyh., Alepidea aquatica Kuntze, and Eryngium amatymbica (Eckl. \& Zeyh.) Koso-Pol [17].

This review is aimed at gathering information on Alepidea amatymbica that covers its traditional use, phytochemistry, pharmacological activity, and toxicology and at highlighting the opportunities for greater development of the plant's medicinal properties at a local and international level.

\section{Materials and Methods}

During the review, all the synonyms of Alepidea amatymbica (Alepidea amatymbica var. amatymbica, Alepidea amatymbica var. cordata Eckl. \& Zeyh., Alepidea aquatica Kuntze, and Eryngium amatymbica (Eckl. \& Zeyh.) Koso-Pol), derived from the plant list synonyms, http://www.theplantlist.org [17], were employed for the literature search. Key words such as "botany," "pharmacological effects," "toxicological effects," and "traditional uses" of Alepidea amatymbica were used for the literature search. Searches were done on the following databases: Google Scholar (http://scholar.google.com), Science Direct (http://www.sciencedirect.com), PubMed (http:// www.ncbi.nlm.nih.gov/pubmed), and Scopus (http://www .scopus.com).

\section{Traditional Medicinal Uses}

Various ranges of traditional uses of Alepidea amatymbica were reported in the literature, from simple uses for conditions such as malaria, diarrhea to cold, coughs, influenza, chest complaints, and wound to complex uses for the management of asthma and rheumatism. For asthma treatment, grounded samples of Alepidea amatymbica rhizome are combined with cannabis for the washing of the divining bones [18]. Our literature search identified citations for traditional use in six countries and these countries are located in Southern Africa (South Africa, Swaziland, Lesotho, and Zimbabwe) and East Africa (Kenya, Ethiopia). In traditional medicine, Alepidea amatymbica is used for the treatment of minor ailments (e.g., sore throat, cough, and influenza) and complications (inflammation, asthma, diarrhea, abdominal cramps, wound, and rheumatism). The ethnomedical uses of Alepidea amatymbica are listed in Table 1. In Zimbabwe, $A$. amatymbica is considered as one of the ten most recognised medicinal plants, locally used as a remedy for asthma, influenza, diarrhoea, and abdominal cramps and to treat colds, coughs rheumatism, and wounds [14, 19]. This species is highly regarded as a remedy for respiratory tract infections, asthma, sore throat, gastrointestinal complaints, fever, rheumatism, bleeding wounds, and headache and extracts are also reported to be active against HIV [2].

3.1. Posology (Dosage). A. amatymbica is used for the treatment of colds and chest complaints Watt \& Breyer-Brandwijk [10], as well as for asthma, influenza, diarrhoea and abdominal cramps, sore throat, and rheumatism $[7,12,36]$. For respiratory complaints (cough, cold, and influenza), 
Table 1: Traditional uses of Alepidea amatymbica Eckl. \& Zeyh.

\begin{tabular}{|c|c|c|}
\hline Category of use & Description of traditional dosage & References \\
\hline \multirow{3}{*}{ Cultural and dietary } & $\begin{array}{l}\text { The dry rhizome and roots are smoked or powdered and taken as a snuff by diviners } \\
\text { and healers to assist in divination and communication with ancestors }\end{array}$ & {$[20-22]$} \\
\hline & Smoking the roots reportedly results in mild sedation and vivid dreams & {$[22]$} \\
\hline & The dry rhizome and roots are used as a lotion to wash the divining bones & [23] \\
\hline Antihypertensive & Fresh rhizomes & {$[22,24]$} \\
\hline Nervousness & Dry rhizome and roots & {$[25]$} \\
\hline Antimicrobial & Leaf, stem, rhizome, and root & {$[8,22]$} \\
\hline Diuretic effects & Fresh rhizome & {$[22,24]$} \\
\hline Respiratory & $\begin{array}{l}\text { Rhizomes and roots are used for colds, coughs, and influenza and respiratory } \\
\text { ailments }\end{array}$ & {$[7,10,21,22,25,26]$} \\
\hline Inflammatory conditions & Rhizomes and roots are used for rheumatism and wounds & {$[10,21,22]$} \\
\hline Gastrointestinal & Rhizomes and roots are used for stomach & {$[10,21,22]$} \\
\hline Purgative & Rhizomes for the treatment of abdominal disorders & {$[7,27]$} \\
\hline Mild sedation and vivid dreams & Smoking the roots & {$[20,28]$} \\
\hline Antimalaria & Rhizome & {$[29]$} \\
\hline Astringent & Fresh rhizome is applied externally & {$[7,12]$} \\
\hline
\end{tabular}

the recommended adult dose is one tablespoonful of raw or cooked rhizome and root; for children one to two teaspoonfuls, according to age, is sufficient. Fresh or cooked rhizome and roots are chewed or sucked, and fresh rhizome is also applied externally as a styptic $[7,12]$. The dry rhizome and roots are smoked or powdered and taken as a snuff by unspecified diviners and healers in South Africa to assist in divination and communication with the ancestors [20]. Smoke from burning of the dry plant material is inhaled and a root infusion taken orally or administered per rectum as an enema [25]. Smoking the roots results in mild sedation and vivid dreams, and a decoction made of the dried product is taken or fresh rhizomes are chewed. It is also burned and inhaled or administered as snuff $[7,12]$. Zulu herbalists (Izinyanga) prescribe the plant to help prevent nervousness in South Africa [25].

3.2. Contradictions. Alepidea amatymbica rhizome is believed to be used as a diuretic by Somova et al. [24], but the plant was reported by Wright et al. [37], to have no diuretic effect in an overview of plants with putative diuretic effects.

\section{Chemical Constituents}

Some of the phytochemicals isolated and characterized to date from Alepidea amatymbica are showed in Figure 2. These include kaurene-type diterpenoids and their derivatives like ent-9, (11)-dehydro-16-kauren-19-oic acid, ent-16-kauren-19oic acid, wedelia seco-kaurenolide, and 313-acetoxy which is believed to constitute up to $11.8 \%$ of rhizome and root dry mass [20]. The activity of the medicine can most likely be attributed to the diterpenoids it contains, although they have not been tested individually [20]. Several diterpenoid kaurene derivatives have been isolated from the rhizomes and roots of $A$. amatymbica [30, 31, 38]. Lipophilic extracts of the powdered dried rhizomes of A. amatymbica collected in different localities also confirmed the presence of ent-9, (11)-dehydro-16-kauren-19-oic acid (la), ent-16-kauren-19-oic acid (2a), wedelia seco-kaurenolide (3) and (4), and the 313acetoxy derivative of 3 , previously reported as constituents of the roots and aerial parts of A. amatymbica [30]. The extracts contained additional kaurene derivatives not previously reported. A comparative study of dichloromethane extracts of the roots of several Alepidea species showed the presence of kaurene derivatives in every case. The distribution of all the major compounds found in Alepidea amatymbica is summarized in Table 2 . The highly resinous rhizomes contain kaurene-type diterpenoids [30,31].

\section{Pharmacological Reports}

Different pharmacological areas were revealed in the literature search on $A$. amatymbica investigation. These include anti-inflammatory, antibacterial, antifungal, antihelmintic, antimalarial, antihypertensive, and diuretic activities. The summarized detail of the pharmacological studies on $A$. amatymbica was showed in Table 3. However, there is dearth of information in literature on the pharmacological effects of the active principles of A. amatymbica. Hutchings [27] reported the performance of screening tests on the basis of personal communication with a pharmaceutical company indicating the antimicrobial, antihypertensive, and diuretic activity [24].

5.1. Antimicrobial Activity. Crude dichloromethane, petroleum ether, ethanol, and aqueous rhizome extracts demonstrate strong antibacterial activity against both gram-negative and gram-positive bacteria used. However, the crude PE and DCM rhizome extracts exhibited the best MIC $(0.39 \mathrm{mg} / \mathrm{mL})$ against $B$. subtilis, and the rest of the extracts were shown to 


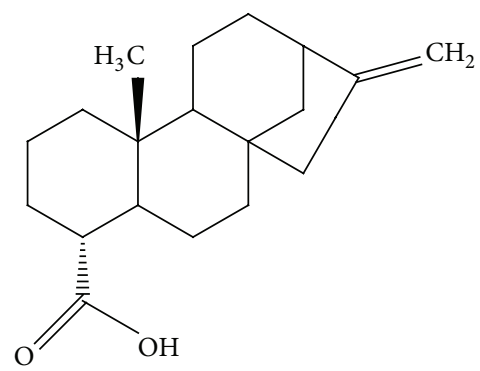

Ent-kaur-16-en-19-oic acid

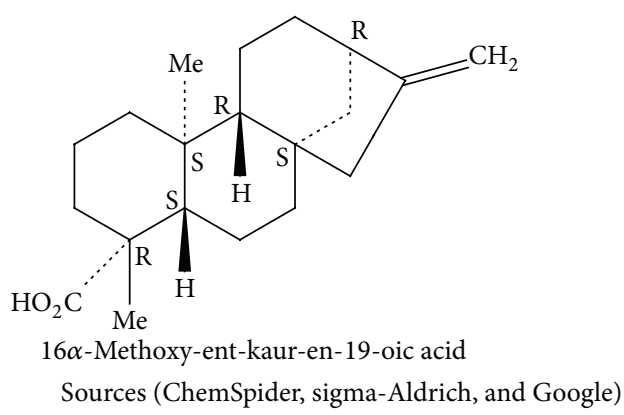

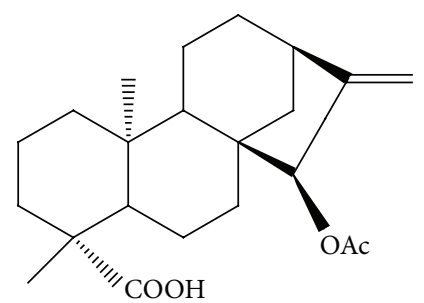

15 $\beta$-Acetoxy-(-)-kaur-16-en-19-oic acid

FIgURE 2: Chemical structures of kaurene-type diterpenoids in Alepidea amatymbica.

TABLE 2: Chemical groups, part of the plant studied, and isolated compounds isolated from Alepidea amatymbica Eckl. \& Zeyh.

\begin{tabular}{llll}
\hline Phytochemicals & Compound & Plant part & Reference \\
\hline & ent-9, (11)-dehydro-16-kauren-19-oic acid & Rhizomes and roots & Dried rhizomes \\
Terpenes & ent-16-kauren-19-oic acid & Dried rhizomes & [30] \\
(kaurene-type diterpenoids) & wedelia seco-kaurenolide & Dried rhizomes & {$[12,30]$} \\
& 313 -acetoxy & Rhizome & {$[30]$} \\
\hline Phenolic acid & Phenolic acid & Rhizome & {$[32]$} \\
\hline Rosmarinic acid & $3^{\prime}$-O- $\beta$-d-Glucopyranosyl rosmarinic acid & & {$[2]$} \\
\hline
\end{tabular}

have low activity (MIC value $>1 \mathrm{mg} / \mathrm{mL}$ ) [6]. The dosage and MIC of the plant extract used in this study showed activity against the bacterial tested when compared to the control. This suggests that the result favors its usage in traditional medicine for the treatment of bacterial infections.

In a related work, the crude extracts of the leaf, stem, rhizome, and root of $A$. amatymbica exhibit a range of antimicrobial properties against the following bacteria: Bacillus cereus, Staphylococcus epidermidis, Staphylococcus aureus, Micrococcus kristinae, Streptococcus pyogenes, Escherichia coli, Salmonella poona, Serratia marcescens, Pseudomonas aeruginosa, and Klebsiella pneumoniae. The acetone rhizome extract showed better activity than others especially on $S$. aureus and $B$. cereus and moderate activity was recorded against the gram-positive bacteria tested with the exception of Micrococcus kristinae [8]. Although the inhibition was high in all the parts of the plant tested, the acetone and methanol stem extract showed a weak activity against Streptococcus pyogenes. This result supports the use of A. amatymbica in treating bacterial diseases associated with respiratory tract, urinary tract, and gastrointestinal tract infections. Due to lack of positive control in this work, it is difficult to draw conclusions on the study. Thus further investigation is required to justify its traditional usage as antibacterial.

The fresh and 90-day dried crude extract of the leaf and rhizome extract of $A$. amatymbica prepared in water, ethanol, and hexane were used in this study [9]. The extracts demonstrated anti- $H$. pylori activity with zone of inhibition range of $0-38 \mathrm{~mm}$ and $\mathrm{MIC}_{50}$ range of $0.06-5.0 \mathrm{mg} / \mathrm{mL}$, respectively. The antimicrobial activity was comparable with the control antibiotics. However, A. amatymbica extracts gave a susceptibility of less than $50 \%$.

The antibacterial activity also increased with storage or ageing of plant material [33]. Antibacterial activity is stable in dry specimens and, as such, may account for the fact that activity is unaffected by storage in certain instances [39]. Therefore, the result favors the use of the plant as an antibacterial considering the activity of the extract and the control even though the dosage was not stated. Hence more work is needed in the validation of the plant extract for the treatment of bacterial infections.

5.2. Antifungal Activity. Antifungal activities of A. amatymbica have been reported $[6,8]$. The crude extracts of the leaf, 


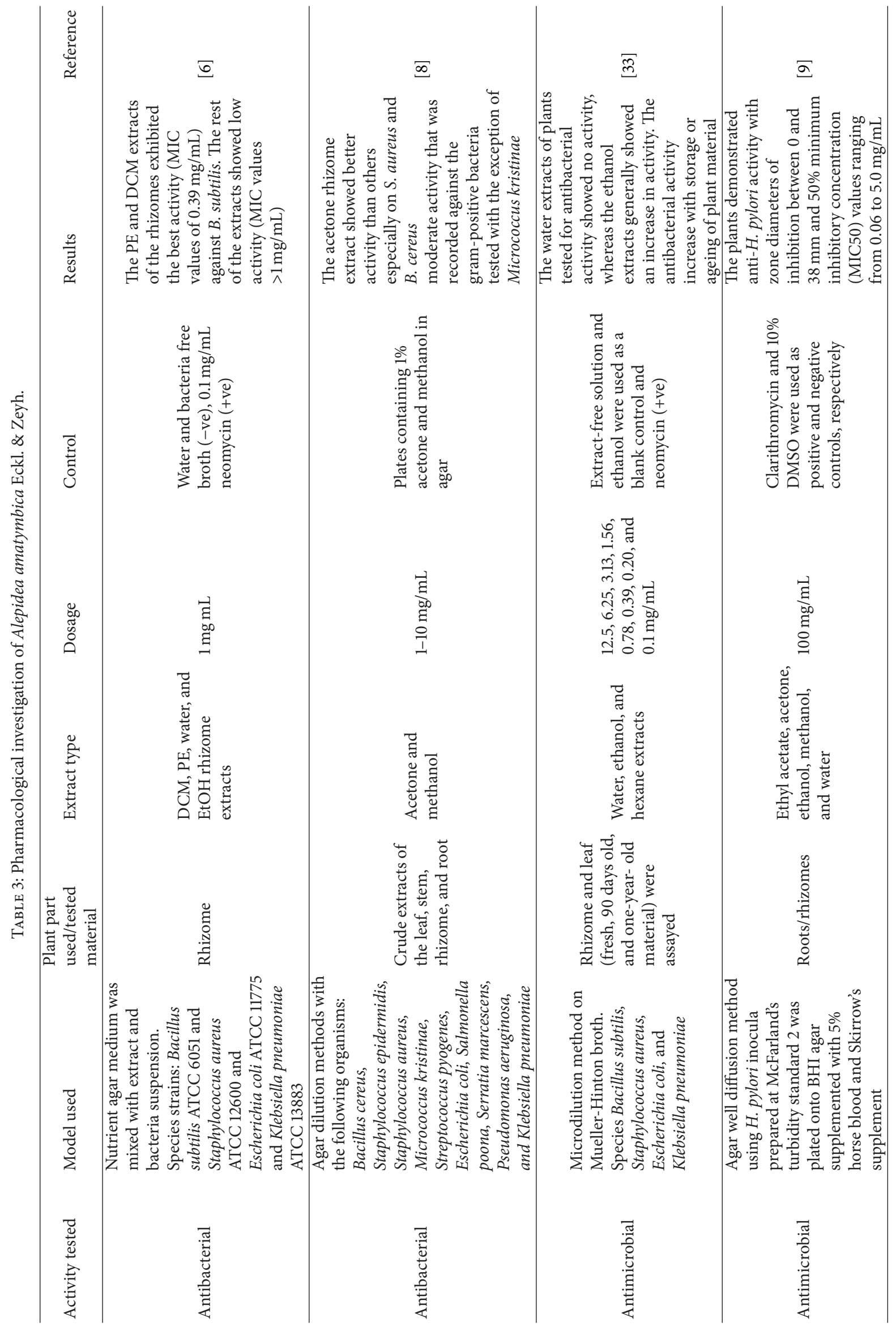




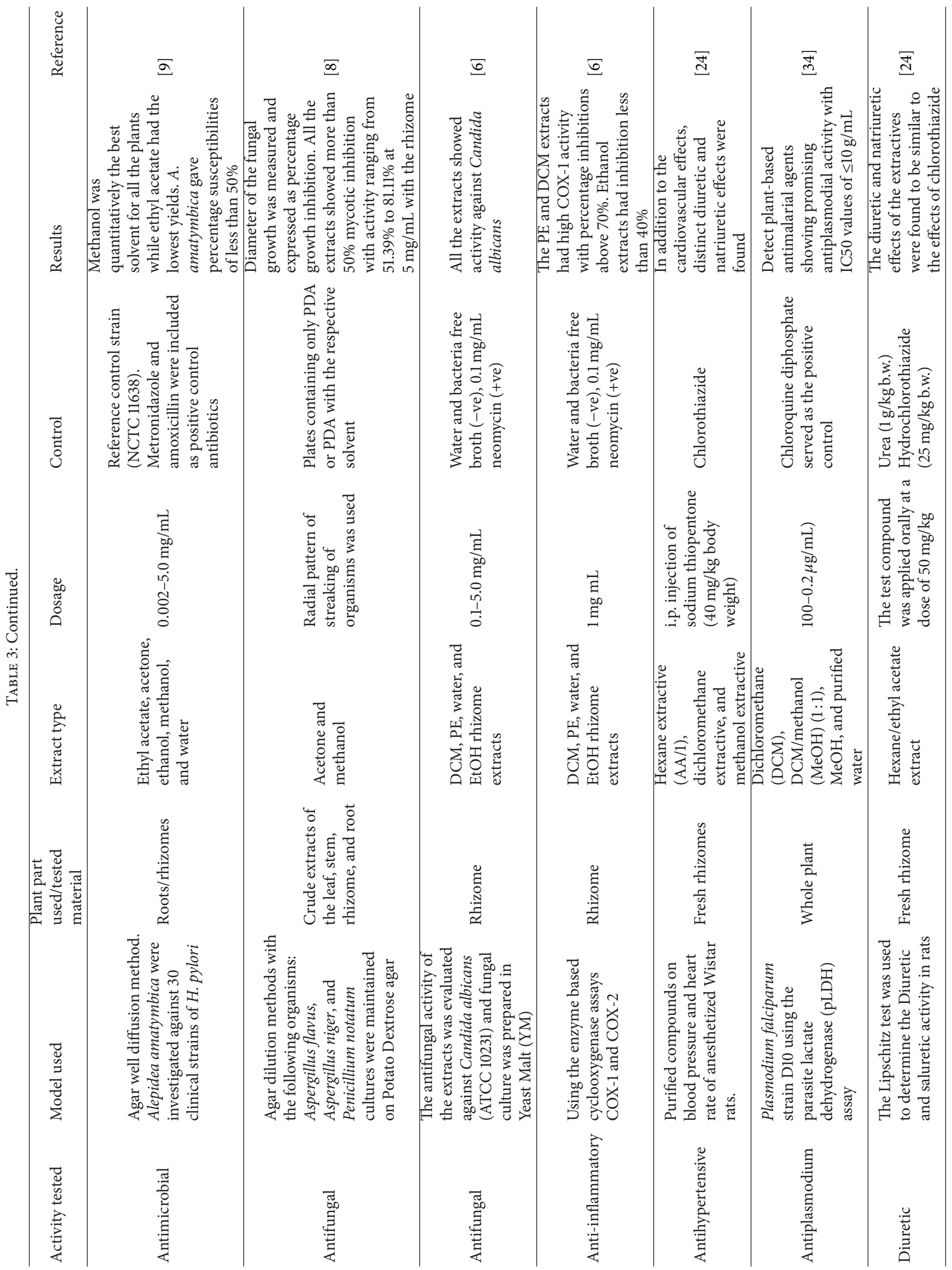




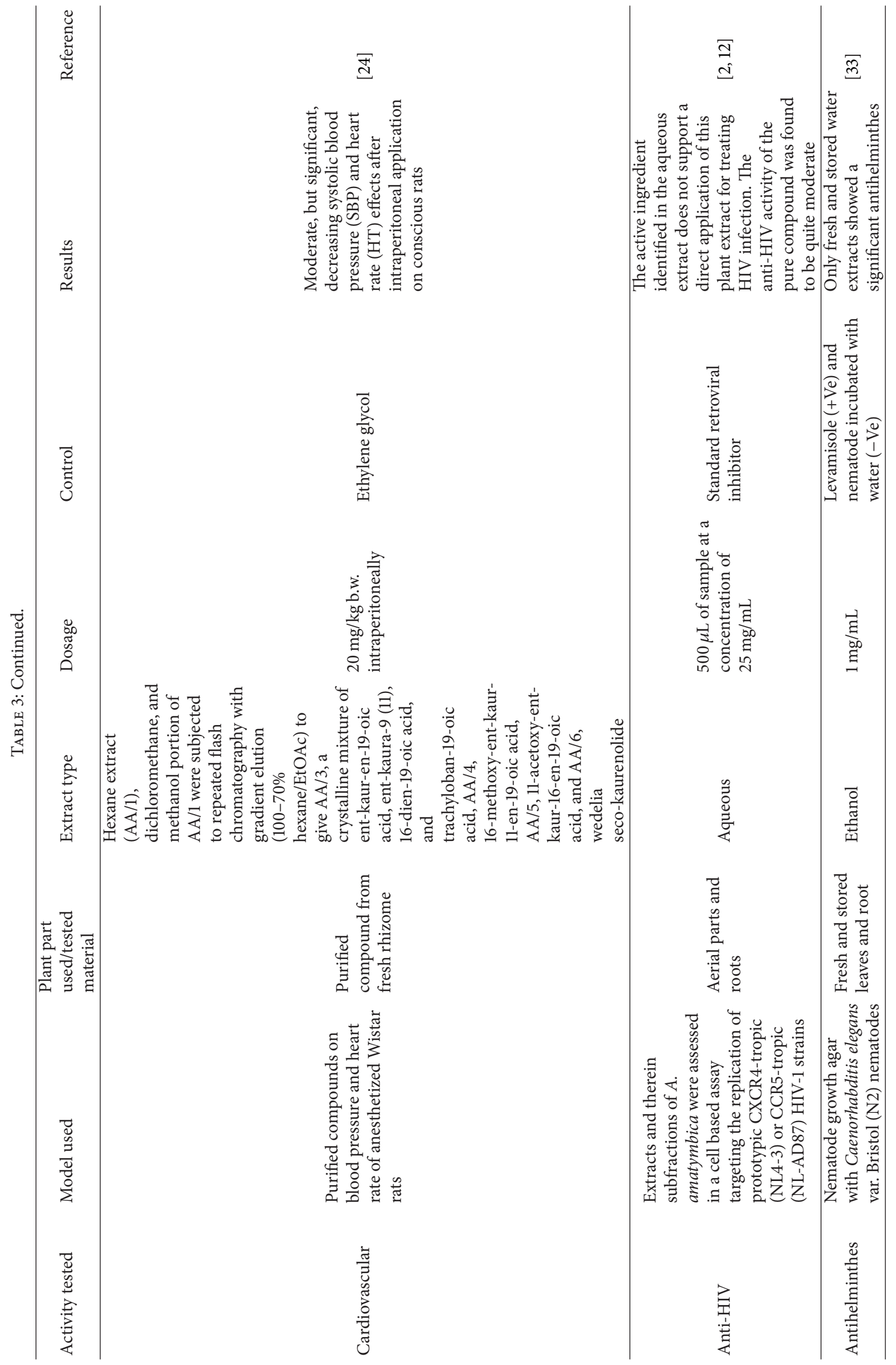




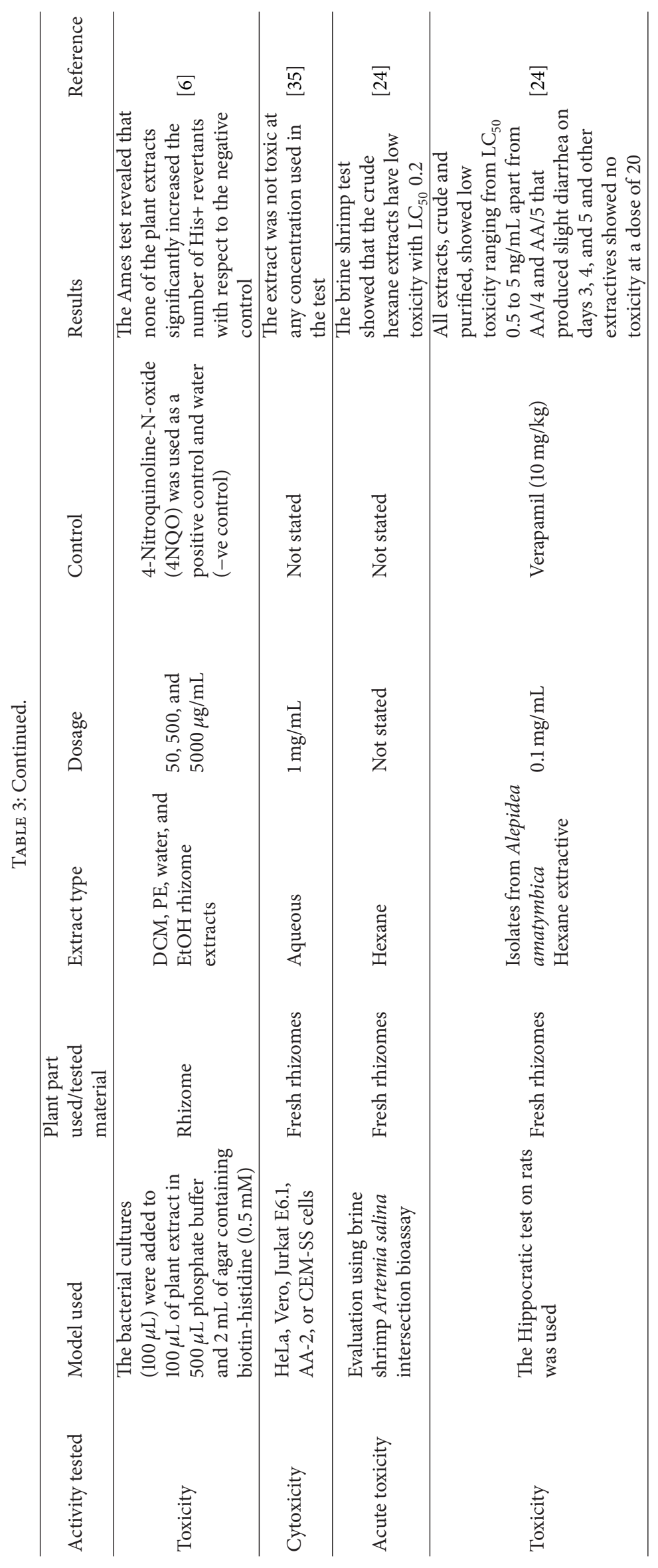


stem, rhizome, and root exhibited activity against Candida albicans extracts and more than 50\% mycotic inhibition against fungal cultures [6]. This study does not provide a dose dependent evidence of the extract and negative control was not used in validating the traditional use of the plant as antifungal. Also, all the extracts except acetone extract showed mycotic inhibition activity against Aspergillus flavus and Aspergillus niger [8]. These results validate the traditional uses of the plant as an antifungal but no dose dependent evidence was given in this study and positive control drug was not used in comparison with the extract used. Therefore, the antifungal activity of the extract cannot be compared with an antifungal drug.

5.3. Antiviral. Louvel et al. [2], investigated the screening activity of the aerial part and root aqueous extract of $A$. amatymbica against a cell-based infection assay targeting the replication of prototypic CXCR4-tropic (NL4-3) or CCR5tropic (NL-AD87) HIV-1 strains designed to detect inhibitors blocking any step of the viral life cycle. The active ingredient identified in the extract does not support a direct application of this plant extract for treating HIV infection. The antiHIV activity of the pure compound was found to be quite moderate. Lack of negative control and a dose dependent activity of the extract make the antiviral activity of the extract inconclusive.

5.4. Antihelminthes. Research was undertaken using nematode growth agar with Caenorhabditis elegans var. Bristol (N2)nematodes on the ethanol extract of the fresh and stored leaves and root of A. amatymbica. Only fresh and stored water extracts showed a significant Anthelminthic [33]. The result of the study did not evaluate a dose dependent inhibition of the extract against the worms, even though the controls were compared with the extract. Further investigation is thus required to validate the use of the plant in traditional medicine as antihelmintic.

5.5. Anti-Inflammatory. The DCM, PE, water, and EtOH rhizome extracts were evaluated using the enzyme based cyclooxygenase assays COX-1 and COX-2 [6]. The PE and DCM extracts had high COX-1 and COX-2 activities with percentage inhibitions above $70 \%$. Ethanol extracts showed higher inhibition $(<40 \%)$ in COX-1 than COX-2. The water extract on the other hand has a moderate inhibition activity $(40-60 \%)$ in COX-1 and lowered in COX-2 $(<20 \%)$. Despite reports on the undesirable effects of higher COX1 inhibition as a result of its damage to the gastrointestinal tract [40], report of Mulaudzi et al. [6] recorded a higher COX-1 in both DCM and PE and a lower COX-1 inhibition in ethanol and water. The result favors the use of water and ethanol as a solvent of extraction for this plant when using it against inflammation. However, conclusion cannot be totally drawn on this report due to lack of negative control and dosage. Hence further investigation is required to provide an evidence for its traditional use against inflammation.
5.6. Antihypertensive. Hexane extractive (AA/1), dichloromethane extractive, and methanol extractive of the fresh rhizome were investigated using purified compounds on blood pressure and heart rate of anesthetized Wistar rats. Moderate, but significant, decrease in systolic blood pressure (SBP) and heart rate $(\mathrm{HT})$ effects after intraperitoneal application on conscious rats was reported [24].

5.7. Antiplasmodium. Dichloromethane (DCM), DCM/ methanol (MeOH) (1:1), $\mathrm{MeOH}$, and purified water extract from the whole plant were investigated on plasmodial activity and were found to contain plant based antimalarial agents showing promising antiplasmodial activity with $\mathrm{IC}_{50}$ values of $\leq 10 \mathrm{~g} / \mathrm{mL}$ [34]. This is the only study showing the dose dependent antiplasmodic activity of the plant extract in relation to the positive control. Validation of the use of the plant in vivo is necessary to conclude the antiplasmodial activity of $A$. amatymbica.

5.8. Diuretic. The purified compounds of the fresh rhizome extracted in hexane/ethyl acetate of A. amatymbica were investigated using anesthetized Wistar rats. The diuretic and natriuretic effects of the extractives were found to be similar to the effects of chlorothiazide drug [24]. The result suggests the inhibitory effect of the extractive of A. amatymbica in reabsorption of $\mathrm{K}^{+}$and $\mathrm{Na}^{+}$ions suggesting the diuretic and natriuretic effects of the extractives. Lack of tested extractive in a dose dependent manner however negates the validation of the plants and the extractives for use as diuretic traditionally. Further investigation is required to provide evidence for its use as a diuretic.

\section{Toxicological Reports}

Four toxicity screens were identified in the literature. Each of the four screens tested uses crude aqueous and organic solvents, hexane extracts, and extractives from the crude hexane extract and none of the reports recorded toxicity at all doses tested. The reported cytotoxicity of the fresh aqueous rhizome was investigated using HeLa, Vero, and Jurkat E6.1, AA-2, or CEM-SS cells. The extract was shown not to be toxic at all concentrations used in the test [35], since the dosage and controls were shown in this study in comparison with the control. The second screens use bacterial cultures $(100 \mu \mathrm{L})$ in an Amen test assay which were added to $100 \mu \mathrm{L}$ of DCM, PE, water, and EtOH rhizome plant extracts in $500 \mu \mathrm{L}$ phosphate buffer and $2 \mathrm{~mL}$ of agar containing biotin-histidine $(0.5 \mathrm{mM})$. The Ames test revealed that none of the plant extracts significantly increased the number of His+ revertants with respect to the negative control [6]. The third test screen utilised the Brine Shrimp Lethal Assay (BSLA). Acute toxicity of the isolates from Alepidea amatymbica was screen against brine shrimp Artemia salina intersection bioassay. The brine shrimp test showed that the crude hexane extracts have low toxicity with $\mathrm{LC}_{50} 0.2 \mathrm{ng} / \mathrm{mL}$, while the AA6 (wedelia secokaurenolide) a derivative of $A$. amatymbica has a low toxicity of $0.5 \mathrm{ng} / \mathrm{mL}$ [24]. The fourth screen made use of Hippocratic test on rats with the use of hexane (AA/1) extract and it's 
extractives in dichloromethane and methanol (AA/1) after subjection to repeated flash chromatography with gradient elution (100-70\% hexane/EtOAc) to give AA/3, a crystalline mixture of ent-kaur-en-19-oic acid, ent-kaura-9 (11), 16-dien19-oic acid, and trachyloban-19-oic acid, AA/4, 16-methoxyent-kaur-11-en-19-oic acid, AA/5, 11-acetoxy-ent-kaur-16-en19-oic acid, and AA/6, wedelia seco-kaurenolide. All extracts, crude and purified, showed low toxicity ranging from 0.5 to $5 \mathrm{ng} / \mathrm{mL}\left(\mathrm{LC}_{50}\right)$ apart from $\mathrm{AA} / 4$ and $\mathrm{AA} / 5$ that produced slight diarrhea on days 3,4 , and 5 and other extractives showed no toxicity at a dose of 20 [24]. Apart from the studies of Treurnicht [35] and Mulaudzi et al. [6] mentioned above, the other studies do not provide sufficient evidence with respect to the safety of $A$. amatymbica considering the absence of dosage used and control in their assays.

\section{Clinical Trials}

To date there appears to be no published research indicating that extracts of Alepidea amatymbica have undergone human clinical trials.

\section{Conclusion}

The review showed that $A$. amatymbica has a widespread use in South Africa and other SADEC countries. The recognition of its ethnomedicinal usage for conditions of inflammation like rheumatism and sore throat to usage for wounds, cough, asthma, influenza, diarrhea, stomach cramps, abdominal disorders, malaria, and diuretic is worth mentioning. The ability of the extract to also restrain the growth of bacteria and fungi indicated its broad spectrum antimicrobial prospective. The pharmacological reports on A. amatymbica revealed therapeutic potential in the treatment of inflammation, malaria, and infectious diseases like influenza, cough, and diarrhea. The frequently occurring chemical constituents of Alepidea amatymbica belong to the kaurene-type diterpenoids and their derivatives. Literature search on A. amatymbica revealed the use of cell line, brine shrimps, and rats for the determination of the toxicity in the plant. More investigations are necessary to explore the medicinal potential of the plant in the management of rheumatism, asthma, hypertension, diuretic, and inflammation. Clinical trials and product development to fully exploit the medicinal value are also required to validate its folklore use in traditional medicine. There is therefore the need to develop the existing traditional use of this plant to amplify nutraceuticals product and commence clinical research to exploit the plant's novel phytochemicals.

\section{Conflict of Interests}

The authors declare no conflict of interests.

\section{Acknowledgments}

The authors are thankful to the Govan Mbeki Research and Development Centre and the National Research Fund of the University of Fort Hare, South Africa.

\section{References}

[1] B. 1. Burtt, "Umbelliferae of southern Africa: an introduction and annotated checklist," Edinburgh Journal of Botany, vol. 48, pp. 133-282, 1991.

[2] S. Louvel, N. Moodley, I. Seibert et al., "Identification of compounds from the plant species Alepidea amatymbica active against HIV," South African Journal of Botany, vol. 86, pp. 9-14, 2013.

[3] G. Germishuizen, N. L. Meyer, Y. Steenkamp, and M. Keith, Plants of Southern Africa: An Annotated Checklist, vol. 41 of SABONET Report, National Botanical Institute, Pretoria, South Africa, 2006.

[4] R. R. Klopper, P. Lemmer, and J. Nel, "Pteridophyta: Pteridaceae cheilanthes deltoidea, a new locality in Gauteng, South Africa," Bothalia, vol. 36, no. 2, pp. 173-174, 2006.

[5] Z. Maksimovic, S. Dobric, N. Kovacevic, and Z. Milovanovic, "Diuretic activity of Maydis stigma extract in rats," Pharmazie, vol. 59, no. 12, pp. 967-971, 2004.

[6] R. B. Mulaudzi, A. R. Ndhlala, J. F. Finnie, and J. Van Staden, "Antimicrobial, anti-inflammatory and genotoxicity activity of Alepidea amatymbica and Alepidea natalensis (Apiaceae)," South African Journal of Botany, vol. 75, no. 3, pp. 584-587, 2009.

[7] A. de Castro and B.-E. van Wyk, "Diagnostic characters and geographic distribution of Alepidea species used in traditional medicine," South African Journal of Botany, vol. 60, no. 6, pp. 345-350, 1994.

[8] A. J. Afolayan and F. B. Lewu, "Antimicrobial activity of Alepidea amatymbica," Pharmaceutical Biology, vol. 47, no. 5, pp. 436439, 2009.

[9] C. Njume, A. A. Jide, and R. N. Ndip, "Aqueous and organic solvent-extracts of selected South African medicinal plants possess antimicrobial activity against drug-resistant strains of Helicobacter pylori: inhibitory and bactericidal potential," International Journal of Molecular Sciences, vol. 12, no. 9, pp. 5652-5665, 2011.

[10] J. M. Watt and M. G. Breyer-Brandwijik, The Medicinal and Poisonous Plants of Southern and Eastern Africa, E and S Livingstone, London, UK, 2nd edition, 1962.

[11] B. E. van Wyk, A. de Castro, P. M. Tilney, P. J. D. Winter, and A. R. Magee, "A new species of Alepidea (Apiaceae, subfam. Saniculoideae)," South African Journal of Botany, vol. 74, no. 4, pp. 740-745, 2008.

[12] J. T. Mukinda and P. F. K. Eagles, "The South African Pharmacopoeia Monograph Project," Developed by South African Traditional Medicines Research Group (SATMERG) and School of Pharmacy, University of the Western Cape. (Unpublished), 2010.

[13] A. Mapaura and J. R. Timberlake, "Southern African plant red data lists," Southern African Botanical Diversity Network (SABONET) Report 14, SABONET, Pretoria, South Africa.

[14] A. Maroyi, "Ethnobotanical study of two threatened medicinal plants in Zimbabwe," International Journal of Biodiversity Science and Management, vol. 4, no. 3, pp. 148-153, 2008.

[15] S. Talukdar, "Lesotho," in Southern African Plant Red Data Lists, J. Golding, Ed., Southern African Botanical Diversity Network (SABONET) Report Number 14, pp. 21-30, SABONET, Pretoria, South Africa, 2002.

[16] R. Scott-Shaw, "Rare and threatened plants of KwaZulu-Natal and neighbouring regions," in A Plant Red Data Book, p. 182, KwaZulu-Natal Nature Conservation Service, Pietermaritzburg, South Africa, 1999. 
[17] The Plant List, 2012, http://www.theplantlist.org/.

[18] S. Nonjinge and B. B. Tarr, Natal National Botanical Garden, 2013, http://www.plantzafrica.com/plantab/alipedeamat.htm.

[19] M. Gelfand, S. Mavi, R. B. Drummond, and B. Ndemera, The Traditional Medical Practitioner in Zimbabwe, Mambo Press, Gweru, Zimbabwe, 1985.

[20] B. E. VanWyk and N. Gericke, 'People's Plants-A Guide to Useful Plants of South Africa, Briza Publication, Pretoria, South Africa, 2000.

[21] A. Hutchings, A. H. Scott, G. Lewis, and A. Cunningham, Zulu Medicinal Plants: An Inventory, University of Natal Press, Scottsville, South Africa, 1996.

[22] B. E. van Wyk, B. van Oudtshoorn, and N. Gericke, Medicinal Plants of South Africa, Briza Publications, Pretoria, South Africa, 1997.

[23] J. A. Guillarmod, Flora of Lesotho, J Cramer, Lehre, Germany, 1971.

[24] L. I. Somova, F. O. Shode, K. Moodley, and Y. Govender, "Cardiovascular and diuretic activity of kaurene derivatives of Xylopia aethiopica and Alepidea amatymbica," Journal of Ethnopharmacology, vol. 77, no. 2-3, pp. 165-174, 2001.

[25] J. Pujol, NaturAfrica: The Herbalists Handbook, Jean Pujol Natural Healers Foundation, Durban, South Africa, 1990.

[26] A. Hutchings and J. van Staden, "Plants used for stress-related ailments in traditional Zulu, Xhosa and Sotho medicine. Part 1: plants used for headaches," Journal of Ethnopharmacology, vol. 43, no. 2, pp. 89-124, 1994.

[27] A. Hutchings, "Observations on plant usage in Xhosa and Zulu medicine," Bothalia, vol. 19, pp. 225-235, 1989.

[28] J. F. Sobiecki, "A preliminary inventory of plants used for psychoactive purposes in southern African healing traditions," Transactions of the Royal Society of South Africa, vol. 57, pp. 1-24, 2002.

[29] S. O. Bandeira, F. Gaspar, and F. P. Pagula, "African ethnobotany and healthcare: emphasis on Mozambique," Pharmaceutical Biology, vol. 39, pp. 70-73, 2001.

[30] A. Rustaiyan and A. S. Sadjadi, "Kaurene derivatives from Alepidea amatynsia," Phytochemistry, vol. 26, no. 7, pp. 21062107, 1987.

[31] C. W. Holzapfel, B. E. van Wyk, A. de Castro, W. Marais, and M. Herbst, "A chemotaxonomic survey of kaurene derivatives in the genus Alepidea (Apiaceae)," Biochemical Systematics and Ecology, vol. 23, no. 7-8, pp. 799-803, 1995.

[32] D. K. Olivier, B. van Wyk, and F. R. van Heerden, "The chemotaxonomic and medicinal significance of phenolic acids in Arctopus and Alepidea (Apiaceae subfamily Saniculoideae)," Biochemical Systematics and Ecology, vol. 36, no. 9, pp. 724-729, 2008.

[33] G. I. Stafford, A. K. Jäger, and J. van Staden, "Effect of storage on the chemical composition and biological activity of several popular South African medicinal plants," Journal of Ethnopharmacology, vol. 97, no. 1, pp. 107-115, 2005.

[34] C. Clarkson, V. J. Maharaj, N. R. Crouch et al., "In vitro antiplasmodial activity of medicinal plants native to or naturalised in South Africa," Journal of Ethnopharmacology, vol. 92, no. 2-3, pp. 177-191, 2004.

[35] F. T. Treurnicht, An evaluation of the toxic and potential antiviral effects of some plants used by South Africans for medicinal purposes [M.S. thesis], University of Stellenbosch, Stellenbosch, South Africa, 1997.
[36] A. Hutchings, Zulu Medicinal Plants, Natal University Press, Pietermaritzburg, South Africa, 1996.

[37] C. I. Wright, L. van-Buren, C. I. Kroner, and M. M. G. Koning, "Herbal medicines as diuretics: a review of the scientific evidence," Journal of Ethnopharmacology, vol. 114, no. 1, pp. 1-31, 2007.

[38] F. O. Shode and B. C. Rogers, "The chemistry of Apiaceae. Isolation and characterisation of diterpenoids and other terpenoids from Alepidea amatymbica," in Proceedings of the 7th International Chemistry Conference in Africa, Durban, South Africa, 1998.

[39] C. W. Fennell, M. E. Light, S. G. Sparg, G. I. Stafford, and J. Van Staden, "Assessing African medicinal plants for efficacy and safety: agricultural and storage practices," Journal of Ethnopharmacology, vol. 95, no. 2-3, pp. 113-121, 2004.

[40] D. Luseba, E. E. Elgorashi, D. T. Ntloedibe, and J. Van Staden, "Antibacterial, anti-inflammatory and mutagenic effects of some medicinal plants used in South Africa for the treatment of wounds and retained placenta in livestock," South African Journal of Botany, vol. 73, no. 3, pp. 378-383, 2007. 


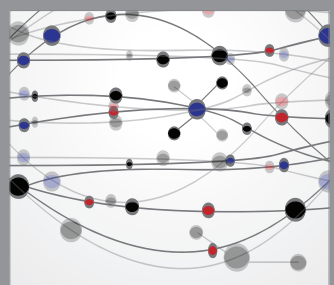

The Scientific World Journal
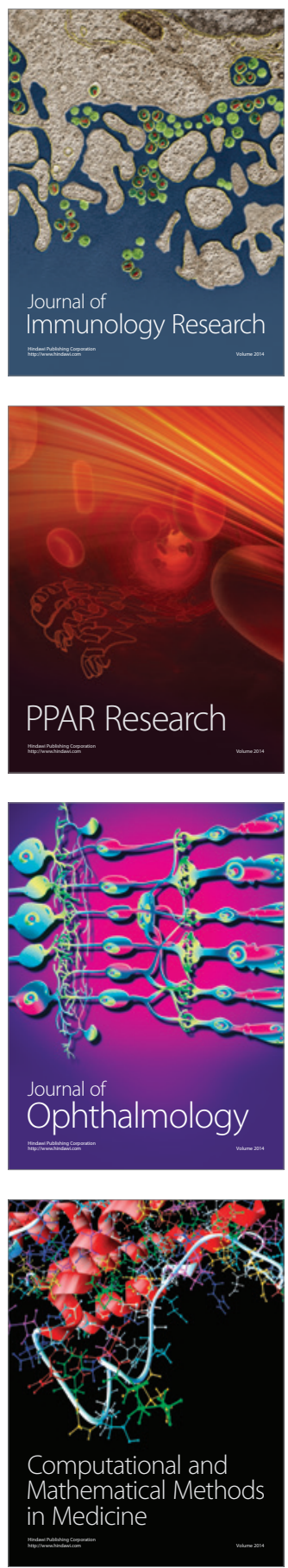

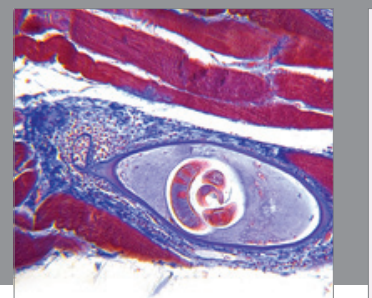

Gastroenterology

Research and Practice
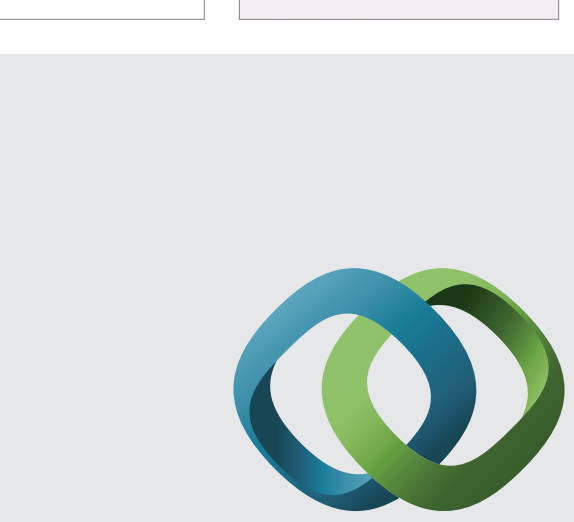

\section{Hindawi}

Submit your manuscripts at

http://www.hindawi.com
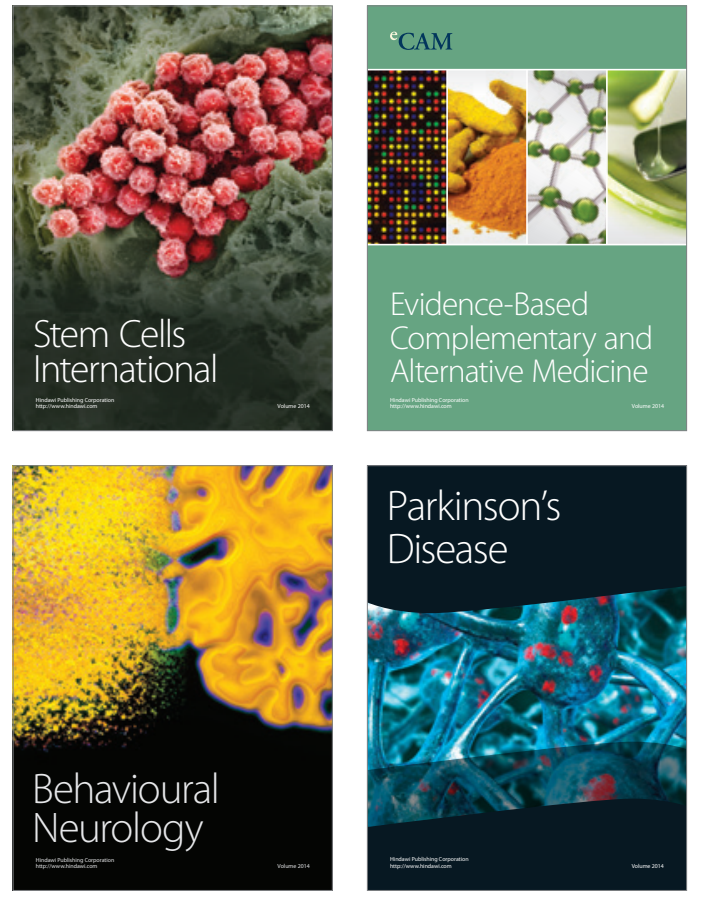
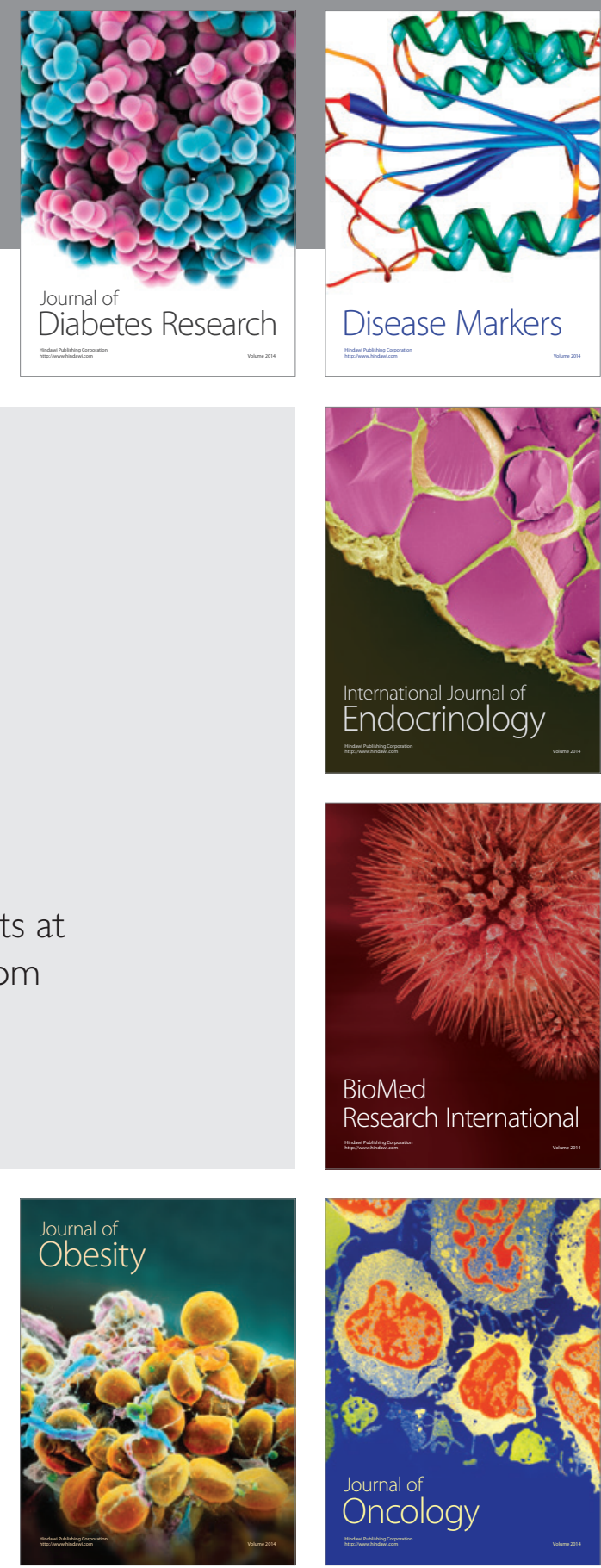

Disease Markers
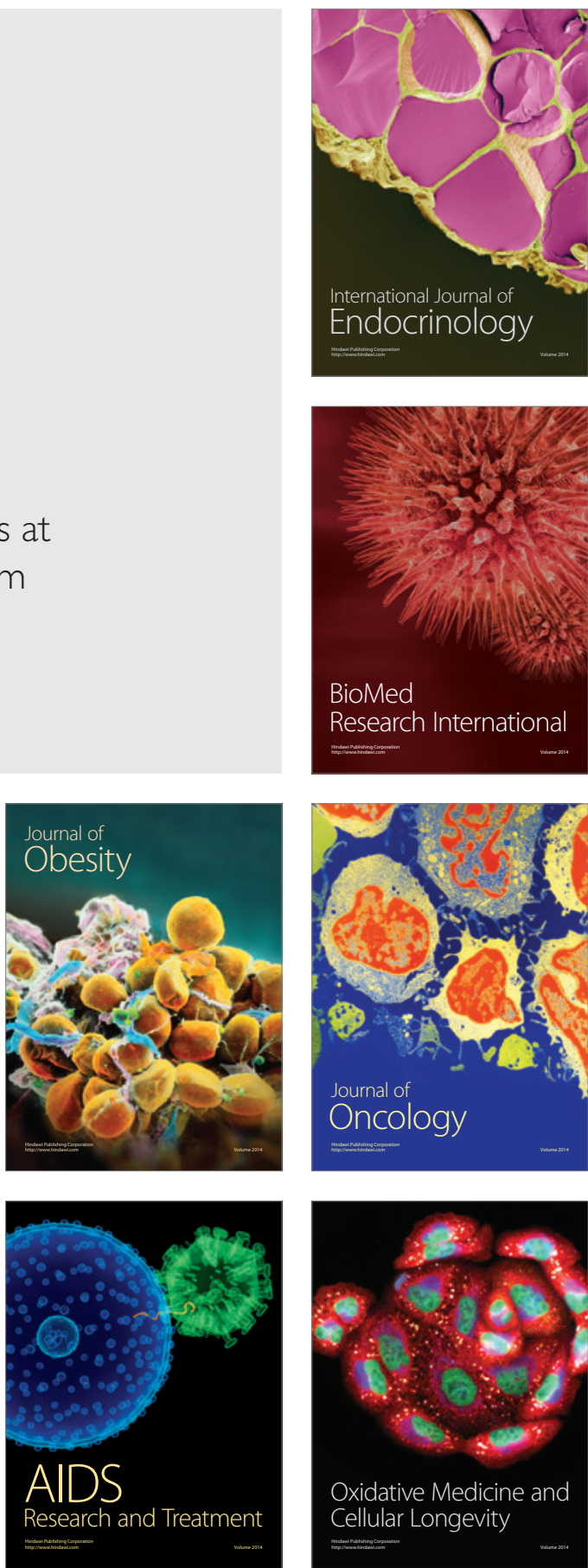